\begin{tabular}{|l|l|l||}
\hline \multicolumn{2}{|c|}{ PublisherInfo } \\
\hline \hline PublisherName & $:$ & BioMed Central \\
\hline \hline PublisherLocation & $:$ & London \\
\hline \hline PublisherImprintName & $:$ & BioMed Central \\
\hline \hline
\end{tabular}

\title{
IL-18 and arthritis
}

\begin{tabular}{||l|l|l||}
\hline \multicolumn{2}{|c|}{ ArticleInfo } \\
\hline \hline ArticleID & $:$ & 91 \\
\hline \hline ArticleDOI & $:$ & $10.1186 /$ ar-2001-68112 \\
\hline \hline ArticleCitationID & $:$ & 68112 \\
\hline \hline ArticleSequenceNumber & $:$ & 48 \\
\hline \hline ArticleCategory & $:$ & Paper Report \\
\hline \hline ArticleFirstPage & $:$ & 1 \\
\hline \hline ArticleLastPage & $:$ & 3 \\
\hline \hline & & RegistrationDate $: 2001-7-26$ \\
ArticleHistory & $:$ & Received \\
& Accepted $2001-3-26$ \\
& $:$ 2001-7-26 \\
\hline \hline ArticleCopyright & $:$ & Biomed Central Ltd2001 \\
\hline \hline ArticleGrants & $:$ & \\
\hline \hline
\end{tabular}




\begin{tabular}{|l|l|l|}
\hline ArticleContext & $:$ & 130753311 \\
\hline
\end{tabular}

Diane Marshall,

Aff1

Aff1 Imperial College School of Medicine, London, UK

\section{Keywords}

IL-18, arthritis, Th1, cytokine

\section{Context}

Interleukin (IL)-18, a member of the IL-1 family of proteins, has previously been shown to be present in the synovium of rheumatoid arthritis (RA) patients (see Additional information [1]). IL-18 has also been shown to be important in sustaining Th1 responses, in the production of IL-8 and macrophage inflammatory protein-1a production, and in increasing IFN-? and TNF-a production by RA synovial membrane cultures, acting synergistically with IL-12 and IL-15. To provide direct evidence for a role of IL-18 in inflammatory arthritis, the authors have compared the development of collagen-induced arthritis (CIA) in IL-18 ${ }^{-/-}$mice and wild-type mice (DBA/1).

\section{Significant findings}

IL-1 $18^{-/-}$mice had a reduced incidence of articular disease, and of those that did develop articular inflammation, the severity of disease (erythema, swelling and extension/loss of function) was reduced in comparison to heterozygous and wild-type littermates. Histology (synovial bone erosion, hyperplasia and cellular infiltration) of hind limb joints was also less severe. Serum concentrations of IFN-?, TNF-a and IL-6 were significantly reduced in IL-1 $18^{-/-}$mice, as were collagen-specific IgG2a antibodies. Cultured spleen and draining lymph node cells from arthritic IL-1 $8^{-/-}$mice proliferated less in response to CII and produced less IFN-?, TNF-a, IL-6 and IL-12. Administration of recombinant IL-18 to IL-18 ${ }^{-/-}$ mice could completely reverse the incidence and severity of articular inflammation.

\section{Comments}


This study provides direct evidence for a proinflammatory role of IL-18 in arthritis, both at the initiation and throughout the chronic phase, thought to be mediated by enhancing Th1 activity and directly inducing proinflammatory cytokines. The study could have been enhanced by determination of the levels of IL-18 in mice with CIA to evaluate any degree of change with disease progression. Of interest, a study by Joosten et al (see Additional information [2]) of IL-18 in nonimmune acute experimental arthritis demonstrated that blockade of IL-18 suppressed joint pathology and reduced synovial cytokine levels. $n$ It would be interesting to determine whether blockade of IL-18 administered during the chronic phase of immune arthritic disease slows down disease progression, hence substantiating the idea that antagonists of IL-18 may have therapeutic potential.

\section{Methods}

Induction of CIA, cell culture, ELISA

\section{Additional information}

Gracie JA, Forsey RJ, Chan WL, Gilmour A, Leung BP, 1. Greer MR, Kennedy K, Carter R, Wei XQ, XU D, Field M, Foulis A, Liew FY, McInnes IB: A proinflammatory role for IL-18 in rheumatoid arthritis. $J$ Clin Invest 1999, 104:1393-1401 (Paper report).

2. Joosten AAB, van de Loo FAJ, Lubberts E, Helsen MMA, Netea MG, van der Meer JWM, Dinarello CA and van den Berg, WB. An IFN-?-independent proinflammatory role of IL-18 in murine streptococcal cell wall arthritis. J Immunol 2000, 165:6553-6558.

\section{References}

1. Wei X, Leung BP, Arthur HML, McInnes IB, Liew FY: Reduced incidence and severity of collageninduced arthritis in mice lacking IL-18. J Immunol. 2001, 166: 517-521.

This PDF file was created after publication. 